\title{
Comparative Analysis of Direct Taxation Rules from Different European Union Countries
}

Maria-Cosmina PINȚEA, ec.

Braşov, Romania

\begin{abstract}
The involvement of our country in the process of European integration is based on removing the inconsistencies and failures of previous reforms, as well as reconciling the objectives of efficiency, effectiveness and equity that lay the foundation for an optimal tax system. Carrying out a comparative analysis of local taxation in the Member States of the European Union could help to remove these inconsistencies, providing an overview and the conclusions drawn can be considered for improving our tax system.

The countries we have chosen to carry out the comparative analysis on are part of both groups of developed economies and emerging economies, so the analysis could be relevant based on almost similar contexts, being part of the European Union. The group of developed countries under observation is made up of Italy, France and Germany, all three of them being founding members of the European Community, while the group of developing countries we chose is made up of Bulgaria, Romania and Poland, all of which are the latest members that adhered to the European Union.

This paper analyses the fiscal pressure borne by taxpayers, at the European Union level, from direct taxes. The correlation between fiscal pressure and direct taxes, in an empirical analysis conducted at microeconomic level, as well as the challenges that the Member State face in their attempt to harmonize direct taxes are also highlighted in this study. Following this comparison, we will be able to assess the impact of direct taxes and to which extent these influence a country's economic development as well as what challenges the governments are currently facing in increasing their amounts of revenues.
\end{abstract}

Key terms: direct taxes, gross domestic product, direct investments, unemployment rate, fiscal pressure, Member States

JEL Classification: K34, H87

To cite this article: Maria-Cosmina Pințea, Comparative Analysis of Direct Taxation Rules from Different European Union Countries, CECCAR Business Review, No 6/2021, pp. 62-72, DOI: http://dx.doi.org/10.37945/cbr.2021.06.08

Both in the EU and worldwide, new challenges have emerged that have exposed the limits of unanimity in fiscal policy both at EU and national level. In today's larger, more modern and more integrated European Union, a strictly state-by-state approach regarding taxation is no longer effective, and harmonization is neither practical nor an effective way of making decisions.

National and common interests are interconnected. Increasing the mobility of businesses and citizens means that a Member State's tax decisions can significantly affect the revenues of other states and the opportunities they have to choose certain policies. Globalization and digitalisation have created common challenges that require common solutions. External competitive pressures, such as the recent US tax reform, require Member States to work together to protect the Union's interests by strengthening the competitiveness of the EU tax system. 
Coordinated EU action in the field of taxation is essential to the protection of Member State revenues and to ensure a fair tax environment for all. In order to keep pace with the current rapidly changing environment, EU fiscal policy needs to be able to react and adapt quickly. However, this is not possible when unanimity is the basic rule. The issues that used to allow debates for years now need to be addressed in a few of them. Given the magnitude of the challenges that the Member States are currently facing, it should not be possible for important decisions to be blocked by a single Member State.

Taxation is the last policy area in the EU in which the decision-making process relies exclusively on unanimity. Through successive changes to the Treaty over the last 30 years, decision-making procedures in other areas have evolved in response to economic, environmental, social and technological changes and produced significant outcomes. Qualified majority voting is currently the general rule, including for policies that are as politically sensitive as taxation. The transition from unanimity to qualified majority voting in other policy areas has not been easily accepted by Member States. However, they have done so because they understand that the EU needs effective decision-making tools to successfully meet modern challenges and to reap the benefits of the single market and economic and monetary union. Some of the most important achievements of European integration in recent decades would not have been possible without this change (Brezeanu and Damian, 2017).

Through this paper we aimed to provide data and information based on which one can correctly assess the size of direct taxes in the six countries analysed related to gross domestic product, direct investment and employment reflected by the unemployment rate of the total population.

\section{Objectives and research methodology}

\subsection{Premises of research}

$\checkmark$ How are the direct taxes reflected in the gross domestic product? Do these taxes impact the economic growth of a country?

$\checkmark$ How do taxpayers feel about the taxes that have a direct impact on their incomes and wealth? What about the legal entities that are operating at international level?

$\checkmark$ Does fiscal pressure from direct taxes influence the decisions of the capital providers?

$\checkmark$ How are countries responding to their need to increase revenues? Are countries adapting the fiscal policy in order to be beneficial for investors, taxpayers or for the government?

$\checkmark$ Does the European Union support countries with low levels of taxation to overcome the challenges? Does it encourage fiscal competition or fiscal harmonization of direct taxes through its Member States?

$\checkmark$ Are Eastern European countries influenced by their former political regimes when adopting new regulations or perspectives on direct taxation? Are the Western countries prepared to support fiscal cooperation with emerging countries?

\subsection{Research objectives}

The purpose of the paper consists in studying, researching, comparing and highlighting the differences in the impact of direct taxes and fiscal facilities granted to enterprises and taxpayers in the Eastern and Western European Union.

The objective pursued requires the achievement of the following goals:

- theoretical examination and research on the notions of direct tax and international collaboration through the double taxation treaties;

- comparison of different statistical indicators from the six countries analysed: Bulgaria, Romania, Poland, Italy, France and Germany.

The first objective would be the quantitative analysis of international experience regarding the accumulation of incomes from direct taxes as percentage of the gross domestic product level of each country. The sources of income from direct taxes are also structured by the type of income taxes, which should also be an important 
factor influencing each country's economy, therefore revealing which sources of financing the budget revenues from direct taxes would also be of interest.

The second objective would be the assessment of the fiscal policy implications on economic development and of the budgetary revenues, as reflected by the stimulation of the foreign direct investments and the unemployment rate over the period under analysis. The evaluation of the tendencies and perspectives of the budgetary system's evolution of Eastern Europe versus Western Europe.

The third objective is the theoretical examination and the research of the direct tax rates and fiscal policies applied by the European Union in respect of the decision-making process and sovereignty of each state.

\subsection{Research methodology}

The research methods consist in the systemic, comparative analysis and in the complex approach of the researched topic, depending on the proposed goals and tasks.

Fiscal pressure is regarded by economist Maxine Yaple as an indicator that shows how heavy taxes are, in other words, how hard the tax burden weighs on taxpayers of legal entities. In order for countries to develop their economies, they need their primary source which is the capital that could be provided by their residents or by foreigners.

Stimulating investment has been a major priority of recent tax reforms, especially in the countries that were heavily affected by the crisis. Efforts have also been made to simplify the business environment in terms of taxation. Most corporate tax systems provide companies with incentives to incur more debt, allowing interest deductions, but do not apply the same treatment to equity. Given that a debt investment benefits from preferential tax treatment, the minimum pre-tax return required to offset the investment ("cost of capital") will be lower for a debt-financed investment, than for an equity-financed investment.

In order to meet the first two objectives, we have conducted a research that involves a quantitative approach at macroeconomic level that follows the fiscal pressure, structure of direct tax revenues and the size of inflows of foreign direct investments as a result of the fiscal policies applied by the countries from the Eastern (Bulgaria, Romania and Poland) and Western Europe (Italy, France and Germany), as Member States of the European Union for a period of nine years from 2010 to 2018.

The starting points of the qualitative approach were the following:

- fiscal pressure is higher in the developed countries and lower in emergent countries;

- direct taxes have a powerful impact on the fiscal revenues of the developing countries and a less powerful impact on the revenues of the developed countries as percentage of the gross domestic product;

- the Eastern countries have an increased capacity of attracting investors compared to the Western countries.

The third objective was researched in the first chapter of this paper, where we have compared the taxation systems by conducting the research on normative acts regulating the fiscal system of the countries under observation, examined the fiscal cooperation between the countries and exposed the main differences between them.

\section{Fiscal pressure regarding direct taxes}

Fiscal coordination is of particular importance in the context of the current record of strengthening public finances, creating budget revenues and supporting economic growth. Concerted action has been imposed at European Union level in order to address the 27 tax systems and eliminate differences with a negative impact on the single market. The European Commission's legislative initiative in areas relevant to the proper functioning of market units, such as taxation of savings income, the energy sector and profit taxation, is encouraged and embraced by all Member States.

Fiscal pressure is the ratio of income from taxes in a given period of time to gross domestic product in the same period. For the analysis of the fiscal pressure, we have used a sample of two groups of European Union 
Member States: from the group of developed countries we chose Italy, France and Germany and from the emerging countries group Bulgaria, Romania and Poland were selected. The analysis period is 2010-2018, the latter being the last year for which statistical data is available.

Direct taxes are set nominally for individuals or legal entities, as a result of groups of income or wealth, depending on the tax rates provided by law. They are collected directly, at certain previously established deadlines, from the subject of tax.

Direct taxes are divided into real and personal. There real taxes are characterized by the fact that the object of taxation is established quantitatively, this category including taxes on buildings, land, industrial and commercial activities and capital. Gradually, because these taxes are set without taking into account the taxpayer's ability to pay, more and more people have switched to personal taxes, that also take into account their personal situation and which generally take two forms: income and wealth taxes.

The following table shows the percentages of direct taxes from the GDP in the two groups of European countries in the period 2010-2018:

Table 1. Fiscal revenues from direct taxes as \% of GDP

\begin{tabular}{|l|r|r|r|r|r|r|r|r|r|}
\hline Country & $\mathbf{2 0 1 0}$ & $\mathbf{2 0 1 1}$ & $\mathbf{2 0 1 2}$ & $\mathbf{2 0 1 3}$ & $\mathbf{2 0 1 4}$ & $\mathbf{2 0 1 5}$ & $\mathbf{2 0 1 6}$ & $\mathbf{2 0 1 7}$ & $\mathbf{2 0 1 8}$ \\
\hline Bulgaria & 5.1 & 4.8 & 4.9 & 5.4 & 5.6 & 5.6 & 5.8 & 6.0 & 6.0 \\
\hline Romania & 5.8 & 6.1 & 5.8 & 5.9 & 6.2 & 6.6 & 6.4 & 6.1 & 4.9 \\
\hline Poland & 6.7 & 6.7 & 7.0 & 6.8 & 6.8 & 6.9 & 7.1 & 7.3 & 7.8 \\
\hline Italy & 14.3 & 14.2 & 14.9 & 15.2 & 14.7 & 14.7 & 14.9 & 14.5 & 14.1 \\
\hline France & 11.5 & 12.1 & 12.8 & 13.2 & 13.1 & 13.1 & 12.9 & 13.3 & 13.7 \\
\hline Germany & 11.1 & 11.5 & 12.1 & 12.3 & 12.3 & 12.5 & 12.9 & 13.1 & 13.5 \\
\hline
\end{tabular}

Source: https://ec.europa.eu/taxation_customs/business/economic-analysis-taxation/data-taxation_en

Regarding the fiscal pressure related to direct taxes, we notice a significant difference between the developed countries and the emerging countries, the former exceeding the EU average in most cases, while emerging countries reach a level about twice as low. The situation in which direct taxes represent the largest share of tax revenues and indirect taxes have a much lower share is characteristic of developed countries. Therefore, this indicator tends to be higher in those countries where income redistribution is an important goal for government authorities, such as Italy or France, and the group of developed countries in general.

Below we have processed the date from the table so the visual representation of the number could be more significant.

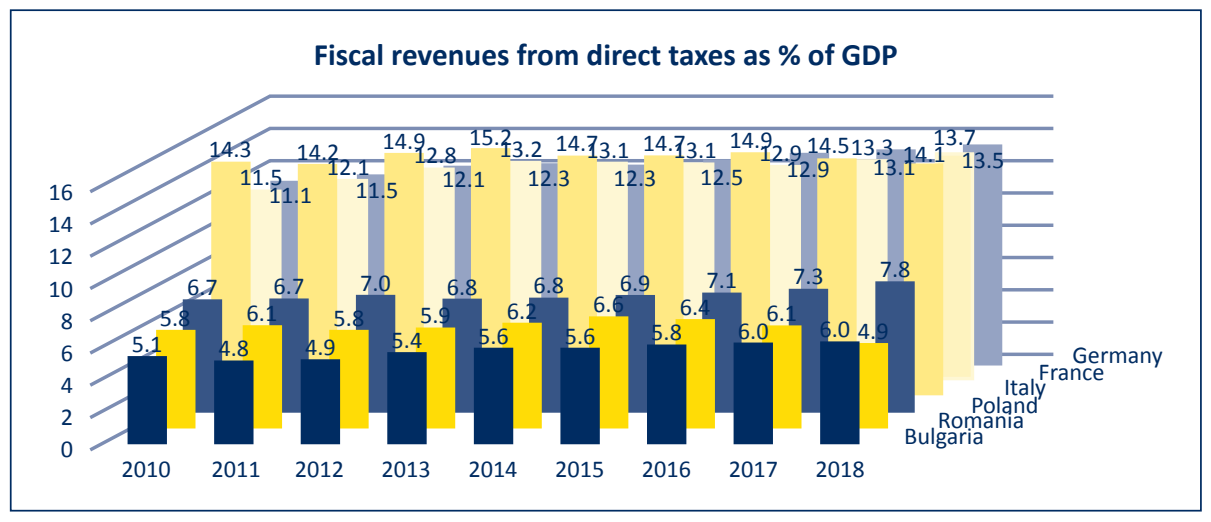

Source: Visual representation developed by the author based on Eurostat data. 
Over the period of time analysed, from 2010 to 2018, the maximum level of direct taxes as percentage of the GDP was reached by Italy in 2013 , with $15.2 \%$, followed by France, with $13.7 \%$ in 2018. Bulgaria recorded the lowest fiscal pressure regarding direct taxes of 4.8\% in 2011 and it has been increasing ever since until 2018.

There had been no substantial increase of the fiscal pressure derived from the direct taxes, keeping an ascending trend, remaining constant from 2017 to 2018. Only two countries, Romania and Italy, have registered a decrease in the direct tax revenue collection.

Poland, unlike Romania and Bulgaria, applies the progressive tax, but uses only three tax rates: people who earn an annual income below 722 euros are not taxed, for incomes between 722 and 20,000 euros a $18 \%$ tax is applied, and those who make more than 20,000 euros pay a tax of $32 \%$. This has been the case since 2009 , and the decrease in the fiscal pressure related to direct taxes took place in that same year, and in the following years an ascending trend could be observed.

In the case of Romania, there were no large fluctuations in this indicator, maintaining the single share of profit and income tax of $16 \%$ throughout the analysed period. Presently, small and medium-sized entities can choose between paying income tax and microenterprise tax.

Two of the other countries analysed recorded approximately the same values throughout this period: Italy (between $14 \%$ and $15 \%$ of GDP) and Bulgaria (between $5 \%$ and $6 \%$ of GDP) fluctuating with only one percentage point.

In Germany, from 1 January 2010, tax rates have gradually increased, from the basic one of $14 \%$ to $42 \%$, and this is also reflected in the increase in the tax burden on direct taxes.

In France, the standard tax rate is 33.33\%, but for 2012 and 2013 an additional rate of 5\% was applied to companies with a gross income of over 250 million euros - this is also reflected in an increase of the analysed indicator. Also, the income tax rates for those with high incomes have increased, in 2011 the upper tax rate having increased from $40 \%$ to $41 \%$.

In Italy, the increase in the tax burden on direct taxes can be explained by the fact that the efficiency of collection has been improved by taking measures in this regard: intensifying tax inspections in conjunction with cross-audits between Member States, and measures to combat tax evasion and signing agreements for the exchange of information.

In order to analyse the impact of direct taxes on economic development of the countries the GDP annual growth is represented below over the same period of time from 2010 to 2018. Obviously, the GDP annual growth is impacted by many other external factors, but the revenues collected by the governments play an important role in the GDP calculation. Direct taxes are part of the revenues collected by the state, so they can influence the GDP.

Table 2. Annual growth of GDP

\begin{tabular}{|l|c|c|c|c|c|c|c|c|c|}
\hline Country & $\mathbf{2 0 1 0}$ & $\mathbf{2 0 1 1}$ & $\mathbf{2 0 1 2}$ & $\mathbf{2 0 1 3}$ & $\mathbf{2 0 1 4}$ & $\mathbf{2 0 1 5}$ & $\mathbf{2 0 1 6}$ & $\mathbf{2 0 1 7}$ & $\mathbf{2 0 1 8}$ \\
\hline Bulgaria & 1.32 & 1.91 & 0.03 & 0.49 & 1.84 & 3.47 & 3.94 & 3.81 & 3.08 \\
\hline Romania & -3.90 & 2.01 & 2.08 & 3.51 & 3.41 & 3.87 & 4.80 & 7.11 & 3.95 \\
\hline Poland & 3.61 & 5.02 & 1.61 & 1.39 & 3.32 & 3.84 & 3.06 & 4.94 & 5.15 \\
\hline Italy & 1.71 & 0.71 & -2.98 & -1.84 & 0.00 & 0.78 & 1.28 & 1.72 & 0.77 \\
\hline France & 1.95 & 2.19 & 0.31 & 0.58 & 0.96 & 1.11 & 1.10 & 2.26 & 1.72 \\
\hline Germany & 4.18 & 3.92 & 0.42 & 0.43 & 2.23 & 1.74 & 2.23 & 2.47 & 1.53 \\
\hline
\end{tabular}

Source: https://databank.worldbank.org/reports.aspx?source=2\&country=BGR\#

Below we have processed the data from the table so that the visual representation of the number is more significant. 


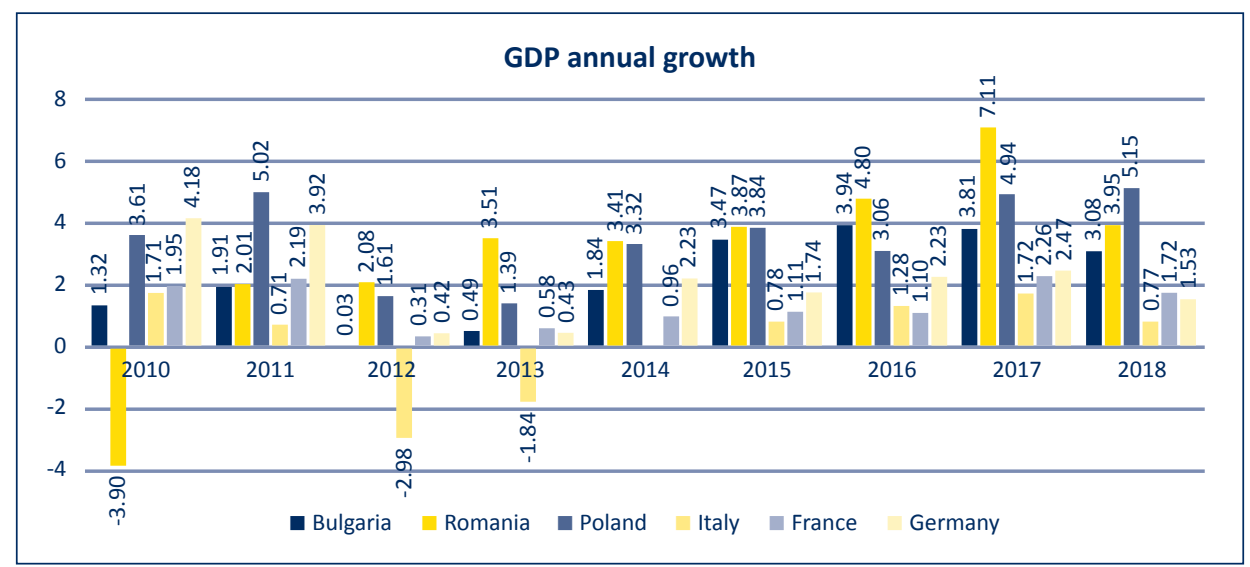

Source: Visual representation developed by the author based on World Bank data.

In the case of Bulgaria, Romania and Poland, we can observe in both graphs that each time a decrease or an increase in the GDP annual growth percentage is registered, an increase or a decrease is registered in the governmental revenues from direct taxes, these being directly proportional. For example, in the case of Romania, in 2017 when we have registered an increase of $7.11 \%$ in the GDP (the highest percentage over the period analysed) the revenues from direct taxes made up 6.1\% of the GDP (but not the highest over the period analysed), while in 2018 when the annual growth of the GDP was of 3.95\% the revenues from direct taxes accounted for $4.9 \%$ of the annual GDP.

Observing the developed countries, we can say that this type of relationship is completely different from the one existing in the developing countries as, for example when Italy registered a decrease in the GDP annual growth in 2012 and 2013 those were the years when Italy also registered the highest level of revenues from direct taxes of $14.9 \%$ in 2012 and $15.2 \%$ in 2013. The indirect proportionality relationship could be also observed in 2010 and 2011, when Germany has registered the highest levels of GDP growth, but the percentages of revenues from direct taxes from GDP have registered the lowest values of $11.1 \%$ and $11.5 \%$ of the total of revenues collected by the state.

To conclude, there are many other factors to be considered when we compare the increase in GDP in different countries, but we can observe that the fiscal policy regarding direct taxes in the less developed countries plays an important role in the total economic growth of those countries, while in the developed countries, it almost has a negative impact on the GDP growth.

\subsection{Direct taxes in the Eastern countries}

The main categories of direct taxes that compose the revenues from these types of taxes are definitely the corporate income tax and the personal income tax. Below we have prepared some diagrams in order to highlight the structure of the direct taxes in each country under observation:

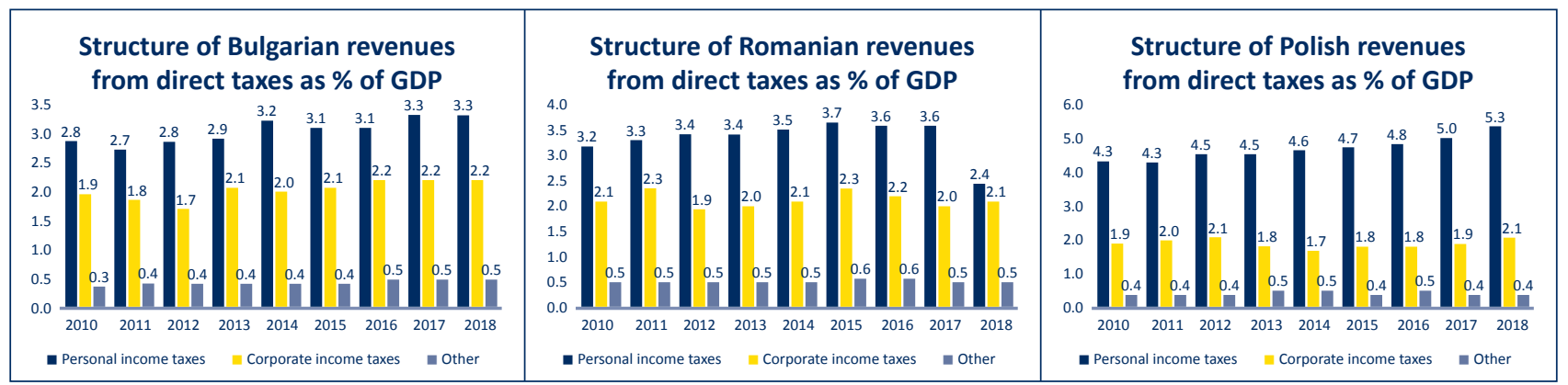

Source: Created in Excel by processing data from Eurostat website, available at https://ec.europa.eu/eurostat/data/database. 
From the above charts one can observe that the highest contribution in the structure of revenues from direct taxes belongs to the personal income tax revenues. In all three countries, the revenues from corporate income tax makes up almost $1.7 \%$ to $2.3 \%$ of the percentage of total revenues from direct taxes, while the other direct taxes are below $1 \%$ from the total.

In the analysis of the fiscal impact of direct taxes on the level of revenues from the Eastern European countries, we could draw attention to Poland, which has the highest level of revenues from personal income taxes (PIT) - of 5.3\% as percentage of GDP registered in 2018 - and we can observe a constant increase in PIT revenues over the whole period under analysis.

In Romania, in 2018, the level of revenues from PIT was $2.4 \%$ and has decreased from the previous year with $1.2 \%$. This might be a result of the latest reforms in the fiscal system regarding the personal income taxation, when the base for personal deductions has decreased to 3,600 lei and the personal deductions have increased. Another reason for which the difference is so significant is the fact that the income tax rate has decreased from $16 \%$ to $10 \%$ from 2017 to 2018.

Over the nine years under observation the corporate income taxes (CIT) and PIT rates applied by Romania were both of $16 \%$, while in Bulgaria both were of $10 \%$. Even though the difference for both taxes was of $6 \%$, the graphs show almost no difference between the percentages of revenues from both taxes, PIT revenues ranging between $2.4 \%$ to $3.6 \%$ and $\mathrm{CIT}$ revenues ranging from $1.7 \%$ to $2.3 \%$. The GDP annual growth has followed an ascending trend, with no significant difference between 2011 and 2017, for these two countries.

In this group of emerging countries, the size of the direct taxes depends on the needs covered by the state budget. The option for these is correlated with the level of income and wealth specific to each country's individuals and legal entities, so direct taxes have a lower yield than the one in developed countries. Hence the choice of indirect taxation mainly over direct taxation for emerging countries.

\subsection{Direct taxes in the Western countries}

The literature highlights that direct taxes are characteristic of developed countries, although some differentiations are known, and developing countries are focused more on indirect taxes than on direct taxes.

Each state is interested in attracting foreign direct investments (referred to as FDI from this point on) in order to develop workplaces for its citizens, attracting financial capital in order to finance investments, strengthening financial markets and obtaining comparative advantages in the provision of financial services. All these interests are the result of fiscal competition in the single market.

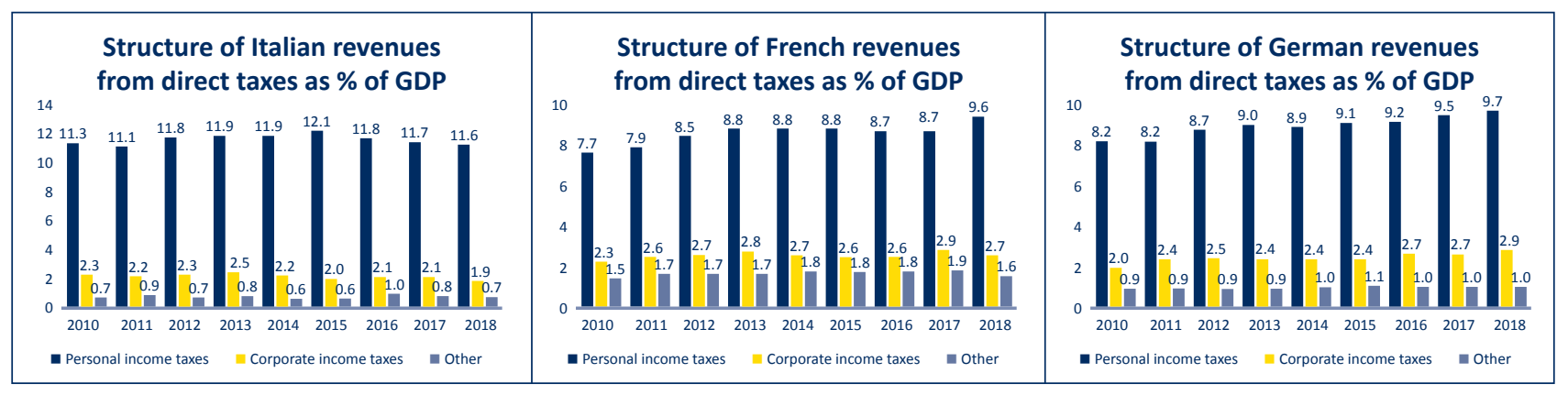

Source: Created in Excel by processing data from Eurostat website, available at https://ec.europa.eu/eurostat/data/database.

The resulting graphs depict the structure of the developed countries' revenues from direct taxes, split also by corporate income tax, personal income tax and other direct taxes. On can observe at first sight that the personal income taxes make up most of the structure of the revenues and that they register values bigger with almost $6 \%$ than the values of the emerging countries.

France and Germany have maintained an ascending trend in the revenues from the PIT over the period analysed ranging from $7.7 \%$ to $9.7 \%$, while the $\mathrm{CIT}$ rate of revenues has not exceeded $3 \%$ of the revenues from 
direct taxes as percentage of the GDP, and only values above $2 \%$. These values could be explained by the fact that these two economies are highly industrialized. An interesting fact is that the category of other direct taxes from Germany has never exceeded $1 \%$ of the revenues, while the portion of the other direct taxes from France recoded values only above $1.5 \%$ to $1.9 \%$ that could be due to the high tax rates applied by French authorities.

Unlike, France and Germany, Italy has recorded significant revenues only from the personal income taxes, compared to the other countries, with quotas ranging from $11.1 \%$ to $12.1 \%$ of revenues from GDP, fact which might be linked with its economic activity: tourism. The CIT revenues percentages of the revenues from the GDP are aligned with the other developed countries under observation and even with the developing countries, while the other direct tax percentages of GDP do not exceed $1 \%$ of the total revenues from direct taxes.

Western countries tend to have increased direct tax rates reflected as revenues in their GDP, since they are strongly industrialised economies. During the analysed period, there were no significant increases in the fiscal pressure related to direct taxes, their level being constant, small even.

\section{The challenges of governments}

Currently, at European Union level, there is no fully integrated European tax system, which marks the way in which the same fiscal policy decision is transmitted at the level of each Member State.

The use of the concept of fiscal competition is presented in the literature as a strategy in which the states in a federation, although they are not cooperating, act as in a game in which several states act in order to establish some parameters for the fiscal system according to the taxes established by others. However, in a few words it means a reduction of taxes and fees, which has as a consequence the possibility that certain categories of taxpayers might opt for the location of their wealth or sources of income to be in those tax residences that satisfy them to the highest degree with the optimal combination between a reduced tax burden and public goods received.

Tax competition at the level of the European Union is the competition between tax jurisdictions, where everyone wants to become more attractive from a tax perspective, for different categories of taxpayers. This competition has brought up some challenges for the Member States such as the attraction of foreign direct investments and the capacity of creating workplaces for their residents or foreigners in order for the governments to increase its revenues.

The irreversible orientation of Eastern and Central European economies towards the market economy have triggered a real interest in Western European investors in the investment market in this area of Europe. The interest of foreign investors is based mainly on the desire to penetrate the markets of these states and the possibility of obtaining cheaper products due to the low level of labour costs. Many studies conducted among Western European investors have come to particularly close conclusions about the motivation of these investors to invest in former communist countries.

Below we have depicted the net inflows of foreign direct investments (FDI) grouped by developed and emerging countries:

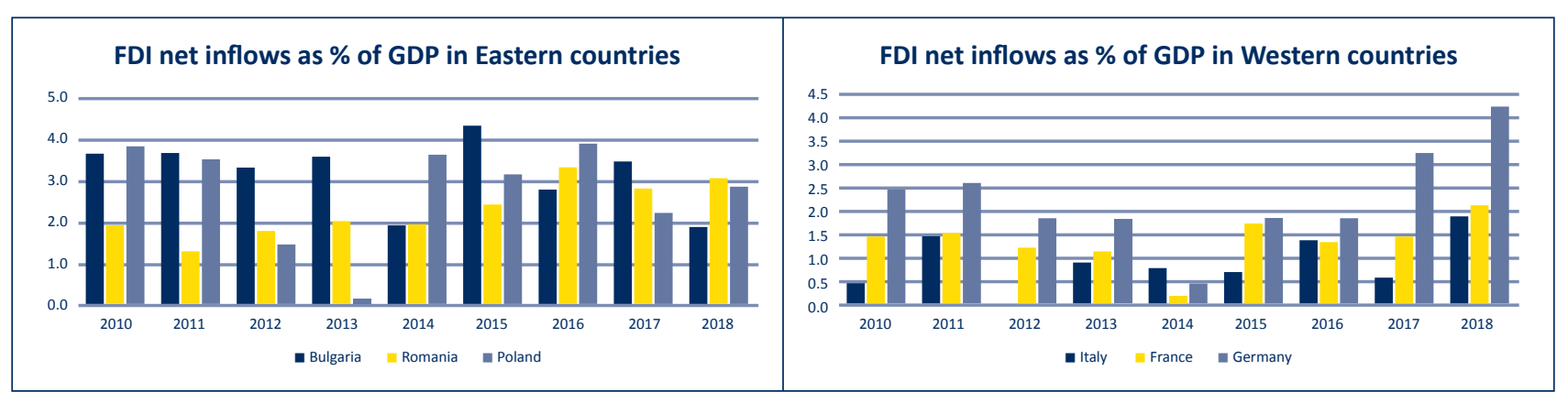

Source: Created in Excel by processing data from the World Bank website, available at https://databank.worldbank.org/ reports. aspx? source=2\&country=BGR\#\. 
As we can see, a high rate of absorption of foreign direct investments is present in the eastern countries, where particularly Bulgaria has reached in 2015 the highest level of inflows from FDI as percentage of GDP, $4.34 \%$. This fact could be explained by the reduced rate of $10 \%$ corporate income tax, which is why investors find Bulgaria an advantageous jurisdiction to bring their capital to.

The degree in which the developed countries of the European Union attract foreign direct investments is significantly lower than the one in the developing economies, as it can be seen in the case of Italy which has registered the lowest level of inflows from FDI in 2012, of 0\% of its GDP. A reason for which Italy has the lowest level of attracting FDIs could be the fact that its economy is based on tourism, and the other two countries, Germany and France, are highly industrialised which could still play an important role in the decision-making process of an investor. Since 2014, Germany has registered an upward trend in FDI, reaching the peak in 2018 with a percentage of $4.25 \%$ of the GDP, having almost reached the highest level for emerging economies.

In the latest years a trend has become popular among the taxpayers to leave the borders of the states of residence, subjecting their tax systems to high tax rates and lots of regulations, which translates into an increase of the tax base and implicitly of the total revenues collected in the host countries. The phenomena of fiscal burden transfer within the EU have become more and more diverse in form and nature. Such trends have also been favoured by the amplification of international capital flows, financial innovations, by the market regulation and the new opportunities for tax evasion, which diminishes the capacity to achieve public financial resources and the registration of fiscal deficits for some Member States.

As a reaction to these imbalances, criticism has emerged especially from the representatives of the developed Member States, who blamed their manifestation on insufficient harmonization of fiscal policies at EU level, but also on fiscal non-coordination which has enabled the governments of the Member States, especially the newly acceded ones, to use fiscal policy instruments as means of allocating taxable matter with high degree of mobility (capital and jobs) in their tax jurisdictions in conditions of fiscal competition.

As a result of the phenomenon of fiscal burdens transfer, the states have tried to encourage the local employment by granting different exemptions or advantages to different companies in order to create workplaces. Below we have presented the evolution of the unemployment rate from 2010 to 2018 for the analysed group of countries.

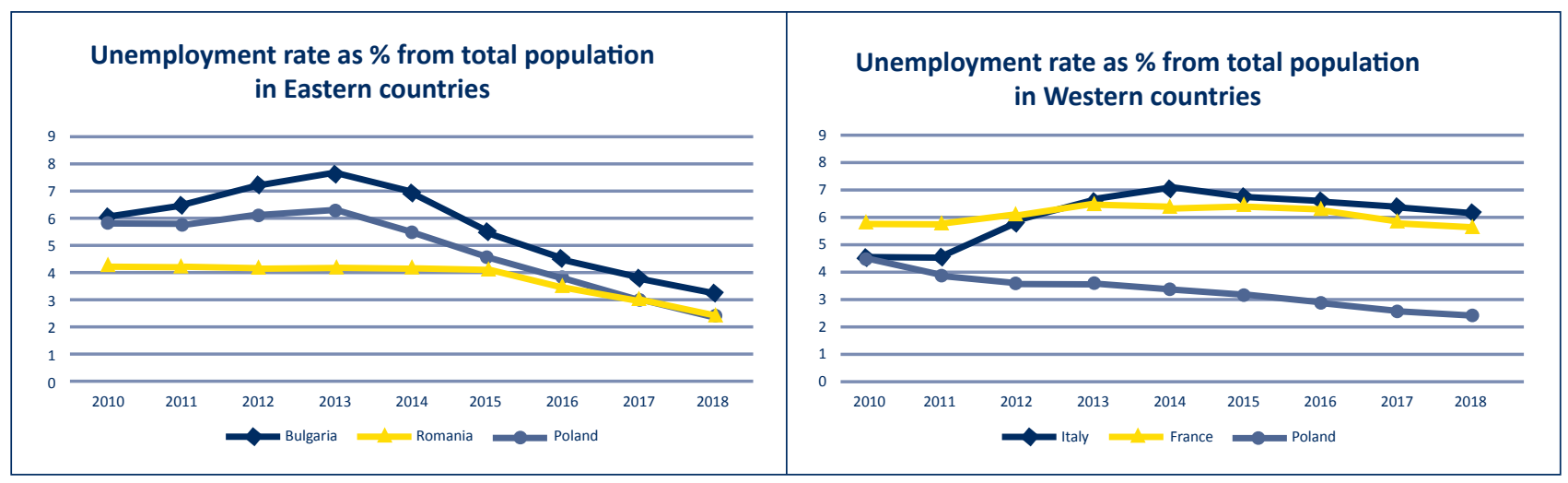

Source: Created in Excel by processing data from the World Bank website, available at https://databank.worldbank.org/ reports. aspx?source=2\&country=BGR\#.

The graph depicting the evolution of the unemployment rate in the Eastern countries shows that the level of unemployment has continued to decrease over the period under analysis, mostly from 2015 to 2018, as a result of the increases in the foreign direct investments attracted by those countries. Bulgaria, Romania and Poland 
are making real efforts in order to decrease the rate of unemployment, so that the revenues from taxes could register increasingly values, by aligning their fiscal policy with the requirements of the European Union while trying to also please the investors and move forward to a more developed economy.

In the graph depicting the evolution of unemployment in the developed countries, only Germany has reached the performance of keeping a downward trend, while Italy has had an increasing trend especially from 2011 to 2014 in the rate of the unemployment. In France the lowest level of FDI inflows have been registered in 2014 and it is noticeable that starting with 2014 the rate of unemployment in France has increased.

The differences between the total levels of taxation actually reflect the differences related to social preferences for public goods.

To date, there is no solid evidence of the impact of the overall level of taxation on economic growth. However, it is better understood how each of the components of the tax regime influences economic growth through the following channels: total factor productivity and increased capital investments or labour supply.

\section{Conclusion}

Given all efforts to harmonize economic and political systems, economic globalization and the intensification of capital mobility also created the necessary conditions for fiscal competition between the EU member states. At present, at the level of the European Union, there is no fully integrated European tax system, which leaves its mark on the way in which the same fiscal policy decision is transmitted at the level each Member State.

Following the analysis, we notice that direct taxes are difficult for the taxpayer in some countries of the European Union. Direct taxes are seen as an additional administrative cost for companies. Although they are unpleasant for taxpayers, they are indispensable to a state. Both direct and indirect taxes are the main revenue to the state budget, and most of them cover public spending.

Fiscal pressure on direct taxes tends to be higher in countries where income redistribution is an important goal of government authorities. Out of the countries under observation, the highest fiscal pressure from direct taxes was registered in Italy, even though the tax rates applied by Germany are the highest from the group of developed countries.

Fiscal harmonization is driven by the need for tax systems not to prejudice the Treaty establishing the European Community. If indirect taxation distorts the free movement of goods and the freedom to provide services, requiring a high degree of harmonization, the same cannot be said about direct taxation, the alignment of which is not expressly provided for in the Treaty establishing the European Community.

The benefits of the harmonization of direct taxes would be the following:

- eliminating discrimination and the risk of double taxation;

- prevention of involuntary non-taxation and tax evasion, especially at the level of intra-community operations;

- preventing the loss of revenue associated with tax competition and weakening revenues, in particular by migrating national tax bases between Member States, in search of a more favourable tax regime;

- reduction of compliance costs due to the inclusion of non-residents under the provisions of several tax systems;

- all Member States could benefit from the advantages of a single market.

Member states have started conducting processes in this direction and direct tax harmonization is currently in full process of realization. Since 2019, France has removed the income tax on revenue associated with overtime work, while the French corporate income tax has decreased from $31 \%$ for fiscal years beginning on or after January 1, 2019 to $28 \%$ for fiscal years beginning on and after January 1, 2020 and to $26.5 \%$ for fiscal years beginning on and after January 1, 2021. 
Another thing worth mentioning is the fact that in 2019 Poland has voluntarily implemented Directive 2018/822, known as DAC6, concerning the Mandatory Disclosure Rule, fact which highlights the endorsement for a harmonised direct tax system. Poland has also introduced a new tax on revenues from the exchange and payment of virtual currencies, which has been in force since 2019. Another sign that the fiscal policy in Poland is encouraging economic development is the investment in the entire Polish territory, by granting a tax exemption for the income obtained by the taxpayers undertaking these investments. Romania on the other side has decreased the personal income tax rate from $16 \%$ to $10 \%$ in order to stimulate the foreign direct investments.

The long practice in the field of foreign investments has proved that foreign investors have always acted with priority in their own interest, even with complete disregard for the national interests of the states benefiting from foreign investments. In the context of growing globalization of economic problems and intensification of integrationist tendencies, the countries in transition have a series of interests converging with those of the developed states, among which should be noted: harmonization of economic development, creating conditions for more intense use of human resources at their place of residence, preventing emigration to industrially developed countries, consolidating democracy in transition countries and eliminating any dangers of reviving communism and creating the necessary conditions for economic and political integration at the level of the entire European continent and achieving the much desired Europe Unite.

Although the harmonization of fiscal policies is an important objective, the system of European public finances accepted by the Member States through the Accession Treaties, with all the efforts made, the priority given to this process has known in time stages of hesitation and interest oscillating as intensity, therefore the degree of harmonization achieved up to present is contrary to expectations and a unitary fiscal policy is not possible yet.

Against the background of the delay of the initially expected results, following the initialization of the harmonization process, Member States with a developed economy like France, Germany or Italy and increased taxation continue to be concerned about the possibility of their sources of budget revenue being reduced through the migration of their potential investors or the relocation of existing ones to low tax jurisdictions, all of which serveas the main arguments for attracting foreign investment. This is the main reason for which those countries are promoting and supporting full harmonization, including in the case of personal income tax, blaming the tax competition they want to reduce or eliminate.

The possible negative or positive effects attributed to tax competition at EU level have varying degrees of support among the member states, as each is somewhat in positions of divergent interest. On the one hand, states with developed economies and the ability to withstand market shocks are against tax competition, while less developed countries like Bulgaria, Romania and Poland are not fully willing to give up the right to collect taxes and fees, judging by the way they dictate the interests of their own fiscal policy. For these countries the fiscal policy remains among the few tools for action at the disposal of national governments to deal with the shortcomings created in the economy by possible crises and shocks propagated in the market.

\section{References}

1. Brezeanu, P., Damian, R.T. (2017), Analiza presiunii fiscale din statele membre ale Uniunii Europene (I), CECCAR Business Magazine, No. 40, https://www.ceccarbusinessmagazine.ro/analiza-presiunii-fiscale-dinstatele-membre-ale-uniunii-europene-i-a2670/.

2. https://databank.worldbank.org/reports.aspx?source=2\&country=BGR\#

3. https://ec.europa.eu/eurostat/data/database

4. https://ec.europa.eu/taxation_customs/business/economic-analysis-taxation/data-taxation_en 